\title{
ENGLISH MEDIUM INSTRUCTION IN ASIAN UNIVERSITIES: SOME CONCERNS AND A SUGGESTED APPROACH TO DUAL-MEDIUM INSTRUCTION
}

\author{
Roger Barnard \\ University of Waikato, New Zealand \\ email: rbarnard@waikato.ac.nz
}

\begin{abstract}
An increasing number of universities across the world are adopting English as the medium of instruction, particularly at the graduate level. This paper begins by briefly describing the historical development of such English medium instruction (EMI) programmes in European universities, and the reasons which are frequently given to justify them. A number of examples of EMI policies in Asian universities are provided to indicate the rapidly growing trend in this region. However, little attention appears to have been paid to some of the negative implications of adopting EMI programmes, and these concerns are articulated here. It is suggested that, instead of adopting strictly monolingual EMI programmes, university authorities should consider a principled approach to dual medium instruction. The value of combining English with the vernacular language is outlined, and a model for such a programme is presented and explained.
\end{abstract}

Keywords: English medium instruction, dual- focused approach, content and language integrated learning

\section{BAHASA INGGRIS SEBAGAI BAHASA PENGANTAR PADA UNIVERSITAS ASIA: BEBERAPA KEKHAWATIRAN DAN PENDEKATAN YANG DISARANKAN UNTUK PEMBELAJARAN BAHASA PENGANTAR GANDA}

\begin{abstract}
Abstrak: Sejumlah universitas di dunia yang jumlahnya terus meningkat mengadopsi bahasa Inggris sebagai bahasa pengantar pembelajaran, khususnya untuk program sarjana. Tulisan ini diawali dengan menggambarkan secara ringkas sejarah perkembangan program pembelajaran dengan bahasa Inggris sebagai bahasa pengantar (EMI) pada sejumlah universitas di Eropa dan beberapa alasan yang sering dikemukakan untuk membenarkannya. Sejumlah contoh mengenai kebijakan EMI di beberapa universitas di Asia ditunjukkan untuk memperlihatkan tumbuh dengan cepatnya pertumbuhan program EMI di wilayah tersebut. Namun demikian, perhatian yang diberikan mengenai dampak negatif atas diadopsinya program tersebut masih terbatas, dan kekhawatiran itu ditekankan di sini. Disarankan bahwa daripada mengadopsi secara kaku program EMI, para pengambil kebijakan di universitas harus mempertimbangkan diadopsinya pembelajaran dengan media ganda. Manfaat mengombinasikan bahasa Inggris dan bahasa nasional atau bahasa daerah setempat dibahas dan sebuah model untuk program seperti itu juga disajikan dan dijelaskan.
\end{abstract}

Katakunci: Bahasa Inggris sebagai bahasa pengantar pembelajaran, pendekatan fokus ganda, pembelajaran terintegrasi antara bahasa dan materi ajar

\section{EMI IN EUROPEAN UNIVERSITIES}

One can trace the contemporary origins of providing instruction of curricular subjects in a second language to two sources in the late 1950s. In Europe, the growth of the European Economic Community led to the establishment of European schools with the mission "to provide a multilingual and 
multicultural education for nursery, primary and secondary level pupils .... primarily the children of staff of the European Communities" (http://www.eursc.eu/index.php?l=2).

Currently, there are 14 such schools across Europe with a total enrolment of 24,000 students. At much the same time In Canada, a number of school authorities sought to emulate the St Lambert experiment (Lambert \& Tucker, 1972) of immersion education: French-speaking children attended schools where the medium of instruction was English, and English-speaking students attended immersion schools in French. Currently there are around 300,000 English speaking Canadian children in approximately 2000 French immersion schools, i.e. $6 \%$ of the total school population in Canada (http://www.unavarra.es/tel21/eng/canada.h tm). The purpose behind both endeavours was the same: to educate linguistically diverse children to meet the challenges and opportunities of increasingly multicultural societies.

In Europe, this approach came to be called Content and Language Integrated Learning (CLIL): "a dual-focused approach in which an additional language is used for the learning and teaching of both content and language" Marsh et al. (n.d). Such programmes in schools rapidly spread as the continent became increasingly united. Among the first institutions of higher education to systematise this was the University of Maastrich where, in 1985, an undergraduate programme in International Management was established. The medium of instruction in the first year was Dutch (initially, all the students were from The Netherlands) and the courses in subsequent years were taught in English, French or German (Wilkinson, 2013). Very soon, the latter two languages were dropped, and the programme continued through English medium instruction (EMI). More universities elsewhere in Europe followed the trend; in 2002 there were over 800 EMI programmes in Europe (Doiz et al., 2013) and by 2008 the number had risen to some 2400, mostly in Germany, the Netherlands and Scandinavia (Wachter \& Maiworm, 2008). Such was the speed of this development that Robert Phillipson began to wonder whether it was an educational panacea, or a pandemic (Phillipson, 2009); were the advantages of EMI considerably outweighed by the disadvantages?

There were several reasons for this spread of EMI (van der Walt, 2013). The initial impetus came from the perceived need to fit domestic students in the various countries for the rapidly globalising economic, scientific and technological world community, for which English was the increasingly dominant language. However, EMI programmes in European universities soon became magnets for a growing number of international students. For such students, learning a new foreign language (German, Dutch, Swedish, etc.) as a precursor to higher education seemed needlessly bothersome, especially as most of them had studied English as their second language for several years. In many cases, the universities sought to attract overseas students in order to enhance their international connectedness - and their academic profile and competitiveness - by establishing exciting new outward-looking programmes. This was soon accompanied by the realisation that they could augment their revenue by charging overseas students different, and higher, fees; the income from such 'clients' became an increasingly important source of revenue to universities at a time when most governments severely reduced their grants-in-aid to institutions of higher education.

\section{EMI IN ASIAN UNIVERSITIES}

By the turn of the present century, a number of British, American and Australian universities had established bilateral relationships with universities in Asia, and elsewhere, to moderate and/or 
co-teach EMI programmes in a range of disciplines. Some of these western universities went further and established their own campuses in countries like Vietnam, Malaysia and Japan, largely with a view to "capitalising on the hard currency of higher degrees earned in English in English institutions "(Van der Walt, 2013, p.63). Seeing this trend, the educational authorities in these, and other, Asian countries saw an opportunity to develop autonomous EMI programmes of their own. Thus, the Vietnamese Ministry of Education instructed universities there to make plans "to use English as a medium in their training programs. Priority should go ... to science, economics, business administration, finance and banking" (MOET, 2005; objective 3, output 2). In Malaysia, public universities mandated the use of the English language in Science and related subjects (Mohini, 2008), and the government allowed, indeed encouraged, an increasing number of private universities to introduce EMI programmes (Tham \& Kam, 2008).

The Japanese government, major industrial and businesses leaders, and private educational authorities have urged universities to offer $10-30 \%$ of their academic courses in English (Brady, 2008, p. 97) but only the International Christian University uses EMI across the curriculum (Van der Walt, 2013, p.65). In 2001, all universities under the control of the Chinese Ministry of Education "were instructed to use English as the main teaching language in the following subjects: information technology, biotechnology, new-material technology, finance, foreign trade, economics, and the law (Nunan, 2003, pp. 595-6). At much the same time, "about ten of the most famous universities in China decided to buy and use almost all of the textbooks being used in Harvard University, Stanford University and MIT (Liu, 2009). Nunan (2003) noted that English has been maintained as a language of tertiary education in Hong Kong, and Li
(2013, p. 66) argues that "the controversies over the past few years were triggered by [his] university management's decision to offer more courses across a wide range of disciplines in English."

More controversy has been caused by the 2006 policy decision at KAIST, a highly prestigious Korean university, that "all lectures ... are given in English in principle to better serve a growing number of graduate and undergraduate students from overseas" (http://www.kaist.edu/ English/01_glance). This decision seems to have had a severe impact on some of the domestic Korean students at this university, as implied in several newspaper articles (Choi, 2011; Jee, 2012); for example, "A 19-year-old KAIST junior student committed suicide Thursday, becoming the prestigious school's fourth student to kill himself in as many months" (Korea Times, 2011). "It is hard to tell whether the requirement to conduct most classes in English at KAIST has something to do with the recent suicides of four students at the school" (Cho, 2011). The president of KAIST "later offered a public apology for the deaths and pledged to abolish financial penalties for low grades and ease the requirement for English-only classes" (Kim, H-j, 2011).

\section{SOME CONCERNS ABOUT EMI}

The possible connection between EMI and student suicides is extremely worrying, but there are other, less personally tragic but nonetheless vitally important, concerns which should be critically considered as EMI continues to be recommended and adopted in Korea and elsewhere. Shohamy (2013) has recently identified a number of these, as they relate to universities in general, and they apply perhaps with even more force in this region as the 'pandemic' spreads. Probably the most immediate question that arises is the linguistic competence of lecturers of academic disciplines to effectively deliver the content of their subject through the 
medium of a second language. Many, of course, may have studied their subject in English-speaking countries to a very high level, but the ability to read widely and write at length in a second language does not necessarily transfer to effectively explaining key concepts to students in such a way as to make the lectures comprehensible.

Some universities seek to employ lecturers for whom one or other variety of English is their first language such a policy is not only expensive but may also lead to cultural as well as linguistic difficulties of mutual adjustment to unfamiliar academic conventions. This leads to the issue of the ability of students to understand instruction in a foreign language, whether by local or overseas lecturers. Local and overseas students in the region may have studied English in schools for seven or more years, but the limited curriculum time in most cases does not allow them to reach a linguistic competence (such as a TOEFL CBT score of 213 or an IELTS score of 6.0) sufficient to pursue their subjects in English.

To some extent, the linguistic limitations of staff and students might be overcome by the use of textbooks written in English and, as was stated above, some universities in China have invested heavily in this solution; others may consider investing in recent technological innovations such as MOOCs (Massive Online Open Courses) developed by universities elsewhere. While this may ease the burden on the lecturer, and allow the students time to understand subject content with the use of print and online resources, there may be a misfit between the underlying cultural assumptions and beliefs of academics in the Asian context and those of authors of textbooks and MOOCs, for example in subjects such as economics, technology or law.

Assuming that these problems can be overcome, or do not arise, it is nevertheless important to consider the extent to which lecturers and students can critically engage with content delivered in English. By such critical engagement is meant both the internal processing involved in individuals attempting to comprehend and evaluate conceptually complex texts, and the further negotiation of meaning through interaction between the lecturer and students, and among the students themselves. Eventually, students need to demonstrate their learning by some form of spoken and/or written academic assignment, and here the use of a foreign language presents two severe challenges: firstly, for students to produce original work at the appropriate academic standard and genre in English (and here the temptations of various forms of plagiarism cannot be overlooked); and, secondly, for lecturers to be able critically (again) to review their students' written English, and then to provide appropriate feedback (in which language?) with a view to helping the students improve future assignments.

These concerns should be sufficient for policy-makers to pause and take stock regarding the implications of EMI within their institutions - but there are also wider linguistic and social issues that need to be taken into account. A strict enforcement of an EMI policy may well lead to a form of linguistic imperialism, defined many years ago by a Ghanaian sociolinguist, as:

The phenomenon in which the minds and lives of the speakers of a language are dominated by another language to the point where they believe that they can and should use only that foreign language when it comes to transactions dealing with the more advanced aspects of life such as education, philosophy, literature, governments, the administration of justice, etc. Linguistic imperialism has a subtle way of warping the minds, attitudes and aspirations of even the most noble in society and of preventing him from appreciating and realizing the full potentialities of the indigenous 
languages. (Ansre, 1979, cited by Phillipson, 1992, p. 56 - emphasis added)

Working only in English, many students may come to think that their own languages - such as Korean, Vietnamese, and Malay - are inadequate vehicles for the transmission of $21^{\text {st }}$ century knowledge. In fact, this is already happening, as fewer and fewer academic and scientific books and articles are published in languages other than English; for example, "more than $95 \%$ of indexed natural science journals and $90 \%$ of social science journals use all or some English" (Lillis \& Curry, 2013, p.229). Thus, there is a vicious cycle operating, to the extent that English can easily be recognised as a killer of languages (Skutnabb-Kangas, 2008) - and cultures - in Asian academia as well as other spheres of life and "if the [local] language is not first put to use in a given function it is hardly likely to develop the relevant linguistic resources." (Nadkarni, 1984, p.154).

Finally, a widespread policy of EMI can have severe social consequences within the society in which it is implemented. The emphasis on competence in English within universities has a washback effect on high schools and even elementary schools in the nation (Ferguson, 2006, p.191; Tsui, 2004, p. 100). Many parents attach enormous importance to the acquisition of English by their children, and they realise that public schools cannot provide sufficient and appropriate instruction to meet the high requirements of subsequent EMI. Therefore, many are sending their children to private after-school classes (for example, juku in Japan, hagwon in Korea) to give them a head start and a leading edge, while others despatch their offspring for relatively long periods of education in English-speaking countries.

The effect is twofold. Firstly, rather than perceiving the goal of a high level of English competence as impossible within the framework of a national curriculum, policy-makers (and parents) perceive language teachers in state-funded schools as deficient, thus devaluing public education. Secondly, the drive for English at all costs widens the educational gap between what the middle classes can afford and that the working classes have to put up with; medium of instruction policies determine which social groups have access to economic and political opportunities (Tsui \& Tollefson, 2004, p.2). "In most markets, the consumers of English language education are the relatively welloff, already far beyond the stage of mere survival. To the extent that severely poor are aware of it at all, the global spread of English is a sideshow compared with the issue of basic economic development and poverty reduction" (Bruthiaux, 2002, p.290).

\section{MONOLINGUAL OR DUAL-MEDIUM UNIVERSITY INSTRUCTION?}

Clearly, there is a need for some emphasis on English instruction to meet the challenges and opportunities of a globalised world dominated by the language. So, across Asia, some universities may teach programmes entirely through EMI - but not all, and perhaps not many.

Most need to resist the temptation of following in the footsteps of universities such as KAIST and become sharply aware of the negative implications of adopting a strictly English-only policy. They should consider the extent to which well-organised bilingual, rather than monolingual, programmes could meet the needs of their students, both domestic and international. It has been said that "using more than one language in spoken and particularly written academic discourse remains one of the 'dark spots' in classroom research" (Van der Walt, 2013, p.130), and case studies such as those presented in Barnard and McLellan (2014) are throwing light on codeswitching practices of university 
teachers in various Asian contexts. They reveal that in all of the English-medium and EFL programmes considered the use of two (or more) languages was normal practice. The teachers involved in these studies gave sound reasons for the use of their, and their students', first language; most felt that they did so in spite of their institutional policies.

Thus it is necessary for institutional language policy-makers to consider the matter very carefully, and make principled decisions about which language(s) should be used to deliver the curriculum. Various options are open, and have been applied in universities elsewhere.

As is suggested by Vivian Cook (2001) and Guy Cook (2010) - and demonstrated in various cases in Barnard and McLellan (2014) - the first language could be used for particular classroom purposes (e.g., explaining difficult concepts) but not for others (e.g., eliciting information from the students, or evaluating their questions). To overcome comprehension problems by students, one university in South Africa (Van Royen, 2005, p. 85), placed an interpreter in the lecture hall who whispered an instantaneous translation of the lecturer's input which the other students heard through radio-microphones. Such a solution may not be practicable in many contexts, but the use of interpreters could be considered in other ways - or example, by the lecturer pausing to allow summary translations.
Another approach would be a strict separation of languages by subject, as is carried out in some universities in Switzerland, South Africa and Finland (Van der Walt, 2013, pp. 133ff). Thus, in particular programmes, individual courses could be taught in the first language and others in English, perhaps depending on the linguistic competence of the staff or students (for example, parallel courses for domestic and international students). Alternatively, separation could be timebased; the content could be taught on three days a week in the first language and the other three in English, whereby the latter would build upon and extend the understanding initially gained. In this way, the languages and cultures could be compared and contrasted.

\section{A MODEL OF SECOND LANGUAGE LEARNING}

The above suggestions may, to some extent, overcome issues of comprehension, but understanding academic content is only the first step learning in a second language; there are also issues of interaction and output. I wish to suggest that implementing some of the above options could pave the way for a systematic approach to dual medium instruction based upon an applied linguistics model of second language learning. Firstly, it may be useful to summarise my understanding of the role that interaction plays in second language learning:

Figure 1. Second language learning: a model

\section{Input}

comprehensible (spoken or written)<smiles>C1CCC1</smiles>

Krashen, 1985

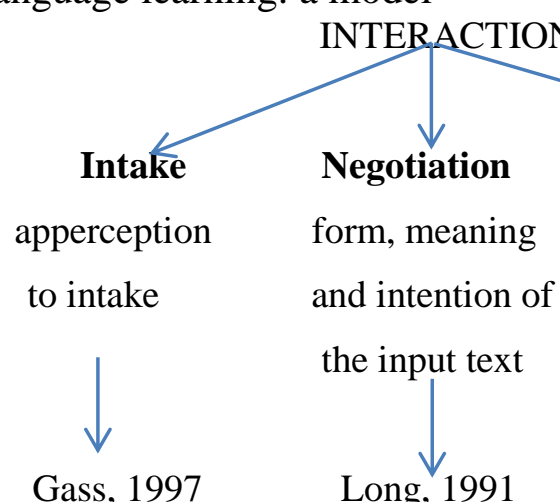

Gass, 1997
Long, 1991

\section{Co-construction}

form, content and

voice of the output

text<smiles>C=CC</smiles>

Van Lier, 1996

\section{Output}

'pushed'

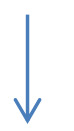

Swain, 1996 
Stephen Krashen (1981) astutely pointed to the distinction between the natural and unforced acquisition of language and conscious and deliberate learning; the above model refers to the latter because it is organised in a pedagogical, rather than a natural, developmental sequence. Krashen remains a controversial figure in applied linguistics, but his insistence that input should be comprehensible is theoretically uncontestable. In practice, however, the principle is not followed in many strictly EMI programmes because the input is so far beyond what the learners can grasp that learning fails to occur. When the input text is only a little beyond the learners' existing linguistic competence, the learners may grasp the meaning, but in order to do so they need - internally - to notice, attend to and process the input in order to move from 'apperception' to intake (Gass, 1997).

For Krashen, effective internal interaction between comprehensible input and a learner's cognitive processing (and an absence of anxiety, which he termed a 'low affective filter') would inevitably lead to acquisition, with no need for the learner to actually produce any linguistic output (Krashen, 1994), However, there does need to be some means by which the input and intake can be explicitly compared, otherwise the learner may not have understood, internalised and evaluated the input. Thus Long's Interaction Hypothesis posits that "negotiation for meaning and especially negotiation work that triggers interactional adjustments ... facilitates acquisition because it connects input, internal learner capacities, particularly selective attention, and output in productive ways" (Long, 1996, pp. 451452 - emphasis in original).

In sharp contrast to Krashen's point of view, Swain $(1985 ; 1995)$ has argued that learners needed to be 'pushed' to produce (written or oral) output in order that their production can be compared to a more 'native-like' version. A sociocultural view (e.g., Donato, 1994, Lantolf \& Thorne, 2007; Van Lier, 1996) suggests that the coconstruction of both the form and content of the eventual text within a zone of proximal development is likely to result in a higher quality production through the sharing and peer-scaffolding of linguistic and extra-linguistic knowledge.

\section{A SUGGESTED APPROACH TO DUAL-MEDIUM EDUCATION}

Such a model of second language learning can be modified and applied to learning academic subject-matter in a dual-medium instructional programme. Principled decisions need to be taken as regards the appropriate language/s to be used in input, interaction and output.

With regard to input, the essential point is that it should be linguistically comprehensible, but it should also be at the appropriate academic level to avoid 'watering down' the disciplinary content of the course. The input text may be written, or spoken (delivered by recording, or directly by the lecturer), or visual, or indeed a combination of all three. Thus if the input text is written entirely in English, as might be the case in a textbook or MOOC, then visual support in the students' first language could be provided in the form of PowerPoint slides with diagrams or glosses or bilingual word lists. Alternatively, of course, the lecturer could orally translate key elements of the text, although this might lead to an excessive amount of codeswitching. On the other hand, the input text might be in the students' first language to ensure comprehension of the content. To form a bridge to eventual texts in English, key terminology or other points in English might be provided to enable the students to work towards bilingual literacy. These annotations could be placed in the righthand margin of a written text, or else presented on PowerPoint slides.

In whichever language the input text is delivered, the students are most likely to 
internally process the information - to make sense of the text - primarily by using their first language. To facilitate this processing, it would be helpful if focus questions or prompts to stimulate their thinking could be posed prior to the delivery of the text, or on Powerpoint slides while the text is being read or listened to, or in the left-hand margins of written texts. Depending on the students' English proficiency and/or their knowledge of the subject matter, these cues could be either in English or in the first language. There also needs to be some means by which the students' uptake (Ellis, 2006, p.100) of the content can be indicated; perhaps they could be asked to write short responses (in either language) to the questions or prompts. These responses could be quickly elicited and checked by the lecturer, or else peer-reviewed.

Essentially, apperception and intake refer to the general content of the message, and the suggestions above would tend to lead to a fairly superficial understanding (uptake) of the text. To get below the surface of both form and meaning, there needs to be some negotiation among the students in groups, and perhaps between students and the lecturer. Such negotiation can be stimulated through a sequence of tasks which move to a deeper understanding of the text, through to a focus on the form in which explicit and implied meanings in the text are conveyed, with particular attention to the specific genre of the text. This would lead to what Van der Walt (2013, p.140) has termed 'co-languaging': students (perhaps with the help of their lecturer) could discuss the ways in which the content of an input text in English is presented at sentence and discourse levels and compare these ways with how their first language would present and structure the content. Once this formmeaning matching has been done, it would be important to move to consideration of the author's voice: the extent to which the writer is presenting facts or opinion, and a critical discussion and evaluation of both. It is most likely that most of the above task negotiation would be in the students' first language to enable an appropriate depth of critical thought and discussion to occur.

Assuming that the input text is in English, a fair amount of lexis and structure in that language would be put in evidence to support the views expressed by the students (and lecturer). Where the input text is in the students' first language, they could draw on their knowledge of English either to suggest how meaning, form and the author's illocutionary intent might be expressed in that language, or else to pose questions that could be addressed when reading subsequent English texts on the same topic. This need not occur only in lecture rooms or classes: Canagarajah (2004) has suggested virtual third spaces, where "the instructor intentionally created space in the 'safe house' for critical reflection and a critique of academic writing" (cited in Michael-Luna \& Canagarajah 2007, p. 70). In whichever language the input text is delivered and discussed, it might be appropriate for the final task in the sequence to require the students to formulate and then write summary points of either the various elements of their discussion, or of the text itself. The language used in these summaries would be the opposite of that used in the input text.

Following the above task-based discussions about the input text, the second phase of negotiation would focus on the task of co-constructing output texts. Here, again, the textual issues of content, form and voice need to be considered and decided; this higher level of contrastive rhetoric focuses on ways by which the functional and generic interrelationships between English and the first languages are encoded and organised. These in-group discussions would enable members to share their linguistic and academic resources, in a form of peer-scaffolding (Donato, 1994; Van Lier, 1996) to enable 
essential decisions about content and form (and perhaps voice) to be jointly constructed. Afterwards, it would be appropriate for the group to divide the task of composing the eventual text among themselves; perhaps they could draft different parts of the text and review one another's work. It would be a matter of the lecturer's discretion as to whether each group would produce one output text, or whether the members would submit individual texts.

In the two preceding discussions, it is assumed that the students (and, where relevant, the lecturer) would majorly use their mutual first language to facilitate effective negotiation of meaning. Depending on circumstances, the language could switch where it is felt that intermediate or final points could usefully be summarised in English.

The choice of which language should be used in the output text is crucial. Written assignments at university level are conventionally viewed as the means by which students demonstrate the extent of their comprehension, engagement with, and evaluation of the content of courses. To the extent that this view is held, it would normally lead to the production of output texts in the students' first language

Figure 2. Dual medium learning: a model -because the students may not be sufficiently competent to fully express their academic knowledge in English, and it might be difficult for the lecturers to provide critical and effective feedback in a second language. Not only should the text be written in the first language, the organisational structure, style and generic features should adhere to norms appropriate to academic discourse in the first language. To do otherwise would be to produce an unseemly hybrid text- hence the importance of the previous discussion of co-languaging. The production of first language texts also makes it possible for lecturers who share the same language as their students to effectively evaluate and assess the academic accuracy and rigour of the texts and - importantly - provide useful feedback to the authors. To move towards bilingual literacy, it could be possible that the students write summaries, or abstracts, of their work in English. Of course, where the English competence of the students (and the lecturers) warrants it, the output texts could be written in English, and appropriately organised, with summaries/and abstracts written in the first language. This suggested dual-medium model is summarised below in Figure 2

$\begin{array}{lllll}\text { Input text } & \text { Intake } & \text { Negotiation } & \text { Co-construction } & \text { Output text } \\ \begin{array}{l}\text { spoken } \\ \text { written } \\ \text { visual }\end{array} & \begin{array}{l}\text { apperception } \\ \text { internal processing }\end{array} & \begin{array}{l}\text { form, meaning } \\ \text { and intention of } \\ \text { the input text }\end{array} & \begin{array}{l}\text { form and content } \\ \text { of output text }\end{array} & \text { 'pushed } \\ \text { in English } & \text { in students' L1 } & \begin{array}{l}\text { in students' L1 } \\ \text { and then English } \\ \text { (or vice-versa) }\end{array} & \begin{array}{l}\text { in students' L1 } \\ \text { and then English } \\ \text { (or vice-versa) }\end{array} & \text { in L1 or English? or L } \\ \begin{array}{llll}\text { 'live' or } \\ \text { recorded }\end{array} & & & \text { Whose genre norms? } \\ & & & & \text { Feedback: } \\ & & & & \text { in L1 or English? }\end{array}$




\section{CONCLUSION}

Students who study a second language, or who are taught though a second language, are - to a greater or lesser extent - already bilingual and, perhaps, bicultural. The above approach has been suggested to stimulate thinking about how this dual identity of students could be transformed to enable them to become bilingually literate academics; essentially, to enable them to comprehend and evaluate academic content in English and rhetorically manipulate it into coherent academic prose in their first language. They should also be able to write shorter academic texts in English, with an eventual view to greater competence in the production of full-length texts in English. This seems a reasonable staged approach towards an ambitious final goal.

The difficulties, even dangers, of a strictly monolingual policy of English Medium Instruction have been outlined above, and fully attested in numerous empirical studies. The first task, therefore, is to advise educational language policymakers of these problems, and to persuade them to consider instead of EMI a principled approach to dual-medium instruction. Some of the suggestions above may prove useful, some may need to be revised, and others replaced by more contextually-sensitive alternatives; in particular, lessons can be learned from the increasing number empirical studies of dual-medium programmes operating in schools and universities (Doiz et al., 2013; Garcia, 2009). In any event, a dual-medium programme needs to be carefully designed and planned to meet the needs and expectations of the target students and lecturers and the resources available. Above all, it is necessary to sensitise all stakeholders to the importance of bilingual academic literacy and to the necessary shift in role perceptions. Such a programme would probably be best to be phased in gradually, stage by stage: first input, then interaction, and then output.
It is hoped that applying a dualmedium model would help to shape the identities of lecturers and students so that they would be academically, bilingually and interculturally competent to meet the challenges of the increasingly multicultural world of the 2 st century.

\section{REFERENCES}

Barnard, R., \& McLellan, J. (Eds.) (2014). Code switching in university English language classes: Asian perspectives. Bristol, England: Multilingual Matters. Brady, A. (2008). Developing a civic educational vision and practice for foreign-additional-other (FAO) language and content integration in higher education. In R. Wilkinson \& V. Zegers (Eds.), Realizing content and language education in higher education (pp. 96-109). Maastricht, Netherlands: Maastricht University Language Centre.

Bruthiaux, P. ( 2002). Hold your courses: language education, language choice, and economic development. TESOL Quarterly, 36(3), 275-296.

Cho, J-h. (2011). English bubble. Retrieved 26 July, 2013 from:

http://www.koreatimes.co.kr/www/ne ws/opinion/2011/05/164_86423.html.

Choi, M. (2011) Feature: KAIST's student suicide crisis. The KAIST Herald, April, 21, 8. Retrieved 26 July, 2013 from http://herald.kaist.ac.kr/news/articleVi ew.html?idxno=156

Cook, G. (2010). Translation in language teaching. Oxford, England: Oxford University Press.

Cook, V. (2001). Using the first language in the classroom. Canadian Modern Language Review 57(3), 399-423.

Doiz, A., Lasagabaster, D., \& Sierra, J.M. (Eds.) (2013). English-medium instruction at universities: Global challenges. Bristol, England: Multilingual Matters. 
Donato, R. (1994). Collective scaffolding in second language learning. In J.P. Lantolf \& G. Appel (eds.), Vygotskian approaches to second language research (pp.33-56). Norwood, NJ: Ablex Publishing Co.

Ellis, R. (2006). Current issues in the teaching of Grammar: An SLA perspective. TESOL Quarterly, 40(1), 83-107.

Ferguson, G. (2006). Language planning and education. Edinburgh, Scotland: Edinburgh University Press.

Garcia, O. (2009). Bilingual education in the $21^{\text {st }}$ century: A global perspective. Chichester, England, Wiley-Blackwell.

Gass, S. (1997). Input, interaction, and the second language learner. Mahwah, NJ: Erlbaum.

Jee, M. (2012) Another suicide hits Korea's top sci-tech university KAIST. The Dong-A Ilbo, April, 18. Retrieved 26 July, 2013 from http://english.donga.com/srv/service.p hp3 ? bicode $=040000 \&$ biid $=201204184$ 9518

Kim, H-j. (2011). Student suicides lead to soul-searching in South Korea. Retrieved 26 July, 2013 from: http://www.student-suicides-lead-tosoul-searching-in-South-Korea.html

Korea Times (2011). Deaths at KAIST :Students' lives cannot be exchanged for school rankings. Retrieved 26 July, 2013 from: http://www.koreatimes.co.kr/www/ne ws/opinion/2011/04/202_84816.html.

Krashen, S. (1981). Second language acquisition and second language learning. Oxford, England: Pergamon Press.

Krashen, S. (1994) The input hypothesis and its rivals. In Ellis, N. (Ed.), Implicit and explicit learning of languages (pp. 45-77). London, England: Academic Press.

Lambert, W.E., \& Tucker, G.R. (1972). Bilingual education of children: The
St. Lambert experiment. Rowley, Mass: Newbury House.

Lantolf, J. \& Thorne, S.L. (2007). Sociocultural theory and second language learning. In B. van Patten \& J. Williams (Eds.). Theories in second language acquisition (pp. 201-224), Mahwah, NJ: Lawrence Erlbaum

Li, D.S.C. (2013). Linguistic hegemony or linguistic capital? Internationalization and English medium instruction at the Chinese University of Hong Kong. In A. Doiz, D. Lasagabaster \& J.M. Sierra (Eds.), English-medium instruction at universities: Global challenges (pp. 65-83). Bristol, England: Multilingual Matters.

Lillis, T., \& Curry, M.J. (2013). English, scientific publishing and participation in the global knowledge economy. In E.J. Erling \& P. Seargeant (Eds.), English and development: Policy, pedagogy and globalization (pp.220242). Bristol, England: Multilingual Matters.

Liu, S. (2009). Globalization, higher education, and the nation state. In Proceedings of the China Postgraduate Network Conference 23-24 April 2009, Luther King House, Manchester (pp. 91-100). Accessed online at http://www. bacsuk.org.uk/cpn/wpcontent/uploads/2012/01/Proceedings2 0091.pdf\#page $=91$

Long, M. H. (1996). The role of the linguistic environment in second language acquisition. In W. C. Ritchie \& T. K. Bhatia (eds.), Handbook of second language acquisition (pp. 413468). San Diego, CA: Academic Press.

Marsh, D., Mehisto, P., Wolff, D., Frigols Martin, M.J (n.d). Framework for CLTL Teacher Education. Frankfurt am Main, Germany: Council of Europe.

Michael-Luna, S., \& Canagarajah, S. (2007). Multilingual academic literacies: Pedagogical foundations for code meshing in primary and higher 
education. Journal of Applied

Linguistics, 4(1), 55-77.

MOET (2005).Vietnam higher education renovation agenda: Period 2006-2020.

Hanoi, Vietnam: Ministry of

Education and Training.

Mohini, M. (2008). Globalisation and its impact on the medium of instruction in higher education in Malaysia. International Education Studies, 1(1), 89-94.

Nadkarni, K. (1984). Cultural pluralism as a national resource: Strategies for language education. In C. Kennedy (Ed.), Language planning and language education (pp. 151-9). London, England: Allen and Unwin.

Nunan, D. (2003). The impact of English as a global language on educational policies and practices in the Asia Pacific region. TESOL Quarterly, 37 (4), 589-613.

Phillipson, R. (1992). Linguistic imperialism. Oxford, England: Oxford University Press.

Skutnabb-Kangas, T. (2008). Linguistic genocide in education - or worldwide diversity and human rights? New Delhi, India: Orient Longman.

Shohamy, E. (2013) A critical perspective on the use of English as a medium of instruction at universities. In Doiz et al. (Eds.), pp. 196-210.

Smit, U. \& Dafouz, E. (2012). Integrating content and language in higher education: An introduction to Englishmedium policies, conceptual issues and research practices across Europe. AILA Review, 25, 1-12.

Swain, M. (1985) Communicative competence: Some roles of comprehensible input and comprehensible output in its development. In S. Gass \& C. Madden (Eds.), Input in second language acquisition (pp. 235-256). New York, NY: Newbury House.
Swain, M. (1995). Three functions of output in second language learning. In G. Cook \& B. Seidelhofer (Eds.) Principle and practice in applied linguistics: Studies in honor of H.G. Widdowson (pp. 125144). Oxford, England: Oxford University Press.

Swales, J. (1990). Genre analysis. Cambridge, England: Cambridge University Press.

Tham, S. Y., \& Kam, A. J. Y. (2008). Internationalising higher education: comparing the challenges of different higher education institutions in Malaysia. Asia Pacific Journal of Education, 28(4), 353-367.

Tsui, A. (2004). Medium of instruction in Hong Kong: One country, two systems, whose language? In J. Tollefson \& A, Tsui (Eds.), Medium of instruction policies: Which agenda, Whose agenda? (pp.97-116), Mahwah, NJ; Lawrence Erlbaum.

Tsui A.B.M. \& Tollefson, J.W. (2004). The centrality of medium of instruction policy in sociopolitical processes. In J.W. Tollefson, \& A.B.M. Tsui (Eds.), Medium of instruction policies: which agenda? Whose agenda? (pp.1-18). Mahwah, NJ: Lawrence Erlbaum Associates van der Walt, C. (2013). Multilingual higher education: Beyond English medium orientations. Bristol, England: Multilingual Matters.

Van Lier, L. (1996). Interaction in the language curriculum: Awareness, autonomy and authenticity. Harlow, England: Longman

Van Royen, B. (2005). The feasibility of simultaneous interpreting in University classrooms. Southern African Linguistics and Applied Language Studies, 23(1), 81-90.

Wachter, B \& Maiworm, F. (2008). The internationalization of higher education: Motivations and realities. 
Indonesian Journal of Applied Linguistics, Vol. 4 No. I, July 20 I4, pp. 10-22

Journal for Studies in International Education, 11(4), 290-305.

Wilkinson, R. (2013). The development of

English-medium education. In A. Doiz,

D. Lasagabaster \& J.M. Sierra (Eds.),

English-medium instruction at

universities: Global challenges (pp. 3-
24). Bristol, England: Multilingual Matters. 